\section{International Archives of \\ Allergy Immunology}

\section{Andrzej Szczeklik}

Department of Medicine, Jagellonian University School of Medicine, Kraków, Poland

Dear Sir,

In their interesting paper, Valent et al. [1] suggest that mast cells might have functions beyond those involved in allergic and inflammatory reactions. Mast cells are the source of both IPA and heparin and are able to include fibrinolysis in vitro. This points to their novel role. The concept that mast cells are involved in endogenous thrombolysis appeals to me, and I would like to support it by the following data.

Atopic patients, who are prone to IgE-mediated mast cell activation, are apparently protected against sudden cardiac death fol-

Int Arch Allergy Immunol 1998;116:166

\title{
Mast Cell, IgE and Atherothrombosis
}

lowing myocardial infarction [2]. They have a mild hemostatic imbalance [3], resembling that produced by aspirin [4]. It is reflected by a moderately prolonged bleeding time [5], depressed platelet aggregability $[5,6]$ and delayed generation of thrombin in clotting blood [7]. In these patients, the generation of a clot inside a critically obstructed coronary artery would be prolonged and delayed because of the late appearance of thrombin. Combined with endogenous thrombolysis linked to mast cell activation [1], this mechanism could protect against sudden cardiac death, the event consistently associated with occlusive coronary thrombi.

Of interest, increased circulating heparin levels have been reported in the blood of atopic patients $[8,9]$, and lack of coronary atherosclerosis was stated at autopsy in patients who died of acute asthmatic attack [10]. Finally, an increased IgE production in response to injury [11] might be associated with enhanced fibrinolysis via mast cell activation. Though some of these arguments need to be confirmed, they deserve, I think, consideration.

\section{References}

1 Valent P, Sillaber Ch, Baghestanian M, Bankl $\mathrm{H}-\mathrm{C}$, Kiener HP, Lechner K, Binder BR: What have mast cells to do with edema formation, the consecutive repair and fibrinolysis? Int Arch Allergy Immunol 1998;115:2-8.

2 Szczeklik A, Dropinski J, Gora F: Serum immunoglobulin $\mathrm{E}$ and sudden cardiac arrest during myocardial infarction. Coron Artery Dis 1993;4:1029-1032.

3 Ind PW: Platelet and clotting abnormalities in asthma. Clin Exp Allergy 1991;21:395-398.

4 Szczeklik A, Krzanowski M, Gora P, Radwan J: Antiplatelet drugs and generation of thrombin in clotting blood. Blood 1992;80:2006-2011.
5 Szczeklik A, Milner PC, Birch J, Watkins J, Martin JF: Prolonged bleeding time, reduced platelet aggregation, altered PAF-acether sensitivity and increased platelet mass as a trait of asthma and hay fever. Thromb Haemost 1986; 56:283-287.

6 Marcia CS, Gallagher JA, Ataman G, Glueck HI, Brooks SM, Bernstein IL: Platelet thrombopathy in asthmatic patients with elevated immunoglobulin E. J Allergy Clin Immunol 1977;50: 101-108.

7 Szczeklik A, Schmitz-Schumann M, Krzanowski M, Virchow C: Delayed generation of thrombin in clotting blood of atopic patients with hay fever and asthma. Clin Exp Allergy 1991;21:411-415.
8 Tanizaki Y, Sudo M, Ono H: Plasma concentration of heparin and its metabolites in bronchial asthma. Jpn J Allergol 1983;32:343-347.

9 Lasser ED, Simon RA, Lyon SG, Hamblin AE, Stein R: Heparin-like anticoagulants in asthma. Allergy 1987;42:619-625.

10 Schoen FJ: Cardiac pathology in asthma. J Allergy Clin Immunol 1987;80:419-423.

11 Szczeklik A, Jawien J: Possible role of IgE in acute phase response. Allergy 1997;52:11491150 .

\section{KARGER \\ E-Mail karger $a k$ karger.ch Fax +41 61306 1234}

www.karger.com (c) 1998 S. Karger AG, Basel

1018-2438/98/1162-0166 \$15.00/0

This article is also accessible online at:

http://BioMedNet.com/karger
Correspondence to: Prof. A. Szczeklik Jagellonian University School of Medicine

Department of Medicine, Skawinska 8

PL-31066 Kraków (Poland)

Tel. +4812 6562840, Fax +48 126565786 